\title{
Dinamika Maslahat dalam Kewarisan Islam
}

Raja Ritonga ${ }^{1 *}$, Andri Muda ${ }^{1}$, Jannus Tambunan ${ }^{1}$, Akhyar $^{1}$

${ }^{1}$ STAIN Mandailing Natal Indonesia

“Korespondensi: rajaritonga@stain-madina.ac.id

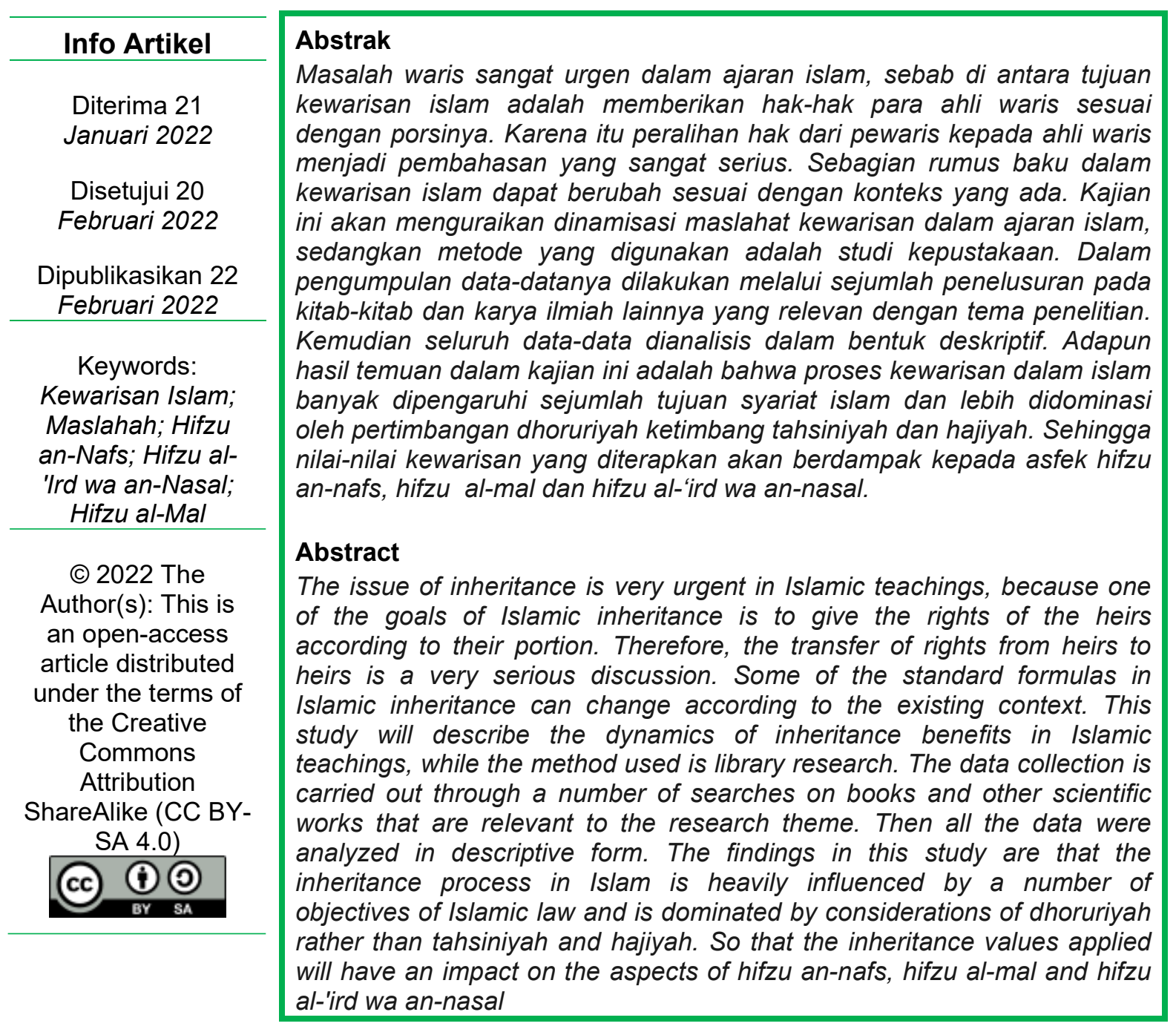

\section{Pendahuluan}

Peraturan dan hukum islam selalu memberikan masalahat bagi umat (Muhammad, 2013). Tidak ada ketetapan hukum yang menyusahkan para mukallaf, sebab semua pelaksanaan hukum dalam ajaran islam mempunyai makna dan hikmah yang akan dirasakan oleh umat manusia (Shidiq, 2009). 
Meskipun hukum itu pada hakikatnya ditujukan kepada umat islam, namun manfaat pada penerapannya akan dirasakan oleh semua makhluk yang ada disekitarnya (Al-'Ulwani, 2001). Itu sebabnya menghadirkan praktek hukum-hukum islam selalu membawa nilai-nilai edukasi yang tidak akan lapuk sepanjang masa (Lisma, 2019).

Kemasalahatan dalam penerapan hukum sangat memberikan dampak positif, tidak terkecuali dalam penerapan hukum waris (Suratmaputra, 2017). Karena pembagian harta warisan sangat diyakini oleh umat islam merupakan sebuah faridhoh, yaitu sebuah kewajiban yang harus dilaksanakan dan tidak bisa ditawar untuk mengubahnya (Basri, 2020). Penentuan bagian di dalam Alqur'an sebuah bentuk final dalam prosesnya. Meskipun demikian, sejumlah permasalahan waris islam tidak luput dari ijtihad para ulama. Hanya saja permasalahan yang masuk ranah ijtihad merupakan dalam hal-hal yang sudah muncul pada masa sahabat (Adnan, 2021).

Peralihan hak atau kepemilikan dari orang yang sudah meninggal dunia kepada orang yang ditinggalkannya adalah sebuah proses dalam kewarisan islam (Naskur, 2010). Keterjagaan peralihan hak dari seorang pewaris kepada ahli waris bagian dari amanat fiqh mawaris dan tentunya juga di dalam peraturan lainnya (Franciska, 2021). Aturan tersebut berlaku secara transfaransi dan sangat detail, sehingga rasa keadilan dapat dihadirkan dalam prosesi tersebut. Pola-pola aturan seperti ini yang diharapkan oleh tujuan pemberlakukan syariat. Karena itu, dapat difahami bahwa tujuan dari syariat islam adalah memberikan kemaslahatan dan keadilan bagi setiap orang (Khotimah, 2014).

Kemudian, ketetapan hukum waris islam tidak berpihak kepada seseorang karena usia, gender, status dan jabatan (Ritonga, 2021a). Hubungan tali nasab dan perkawinan secara otomatis akan menjadi legalisasi atas kepemilikan hak bagi ahli waris untuk mendapatkan bagian warisan(Ritonga, 2021b). Selain itu masingmasing ahli waris akan merasakan asas keadilan pada kewarisan islam tanpa melihat status jenis kelaminnya (Nasution, 2021).

Maqashid syari'ah sering menjadi acuan untuk memberikan petimbangan dalam penetapan hukum (Khodijah Ishak, 2014). Sebab, nilai-nilai maslahat yang terkandung dalam penerapan sebuah hukum akan dirasakan oleh pelakunya (AlBadawi, 1999). Dalam kajian kewarisan islam, sejumlah aspek sangat dipertimbangkan dalam prosesi peralihan kepemilikan. Di antaranya adalah aspek jiwa, keturunan dan harta. Sebab menjaga keturunan (keluarga) merupakan salah satu asfek dari maqashid syari'ah (Jamal, 2010). Dengan memberlakukan konsep waris yang menitik beratkan pada kemaslahatan keluarga tentu akan memenuhi dari maqashid itu sendiri. Dalam ajaran islam menjaga keluarga adalah sebuah kewajiban (Amri \& Tulab, 2018) dan seseorang harus menghawatirkan masa depan keturunannya (Indonesia, 2014).

Lebih lanjut, pada asfek hifzu al-mal (menjaga harta) menjadi bagian yang tidak terpisahkan dan menjadi sangat urgen dalam kajian maqashid syariah (A. Ahmad, 2014) khususnya fiqh mawaris. Sebab, peruntukan hak dan harta diatur secara jelas dan gamblang untuk kemaslahatan ahli waris. Harta tidak akan menjadi fitnah bagi pewaris dan ahli waris. Pintu-pintu khilafiah dapat diredam dan disumbat dengan peralihan harta yang sangat detail. Sehingga hak-hak yang 
berhubungan dengan harta peninggalan pewaris bisa disalurkan sesuai dengan kuota dan peruntukannya.

Kajian terkait kewarisan islam melalui kacamata maqashid syariah atau nilainilai maslahat tentu sangat menarik untuk diulas agar menjadi sebuah pengetahuan yang bermakna bagi umat islam. Karena itu peneliti berusaha memfokuskan kajian ini dalam hal mengungkap nilai-nilai asas maslahah yang ada pada praktek waris islam. Jika dibandingkan dengan penelitian yang dilakukan oleh Sri Lum'atus Sa'adah bahwa kajian tersebut menyimpulkan bahwa pembagian harta merupakan bagian dari ketundukan pada ajaran agama dan merupakan upaya untuk menjaga agama (Sa'adah, 2015). Sementara itu, penelitian yang dilakukan oleh Muchlis Samfrudin Habib menyimpulkan bahwa kewarisan bilateral memiliki relevansi dalam maqshid syari'ah (M. S. Habib, 2017). Kemudian untuk membedakan penelitian ini dengan kajian sebelumnnya, maka peneliti akan memfokuskan praktek kewarisan islam yang mengandung nilai-nilai maslahah dari maqashid syari'ah.

\section{Metode Penelitian}

Adapun jenis penelitian yang dilakukan adalah kajian pustaka atau library research. Pengumpulan data-data dilakukan dengan penelusuran sejumlah kitab, buku, jurnal dan karya ilmiah lainnya yang relevan dengan tema penelitian. Lebih lanjut, data-data yang menjadi temuan dianalisis dengan analisis konten. Sehingga dalam penyajian data yang dilakukan adalah dengan mendeskripsikan hasil temuan dan pembahasan secara detail. Kemudian ditarik kesimpulan melalui penyajian data dan setelah analisis yang dilakukan.

\section{Hasil dan Pembahasan}

\subsection{Waris Islam}

Kewarisan dalam islam dapat dipahami sebagai peralihan hak dari seseorang yang meninggal dunia kepada ahli warisnya yang masih hidup. Peralihan hak kepemilikan tersebut diatur dengan jelas dalam Alqur'an, sunnah Rasulullah Saw serta sejumlah ijtihad para sahabat. Peralihan hak dan kepemilikan akan dianggap sah sebagai warisan prosesi tersebut dilaksanakan setelah meninggalnya seseorang. Selain itu, prosesi peralihan semua warisan dalam islam hanya berlaku bagi ahli waris yang masih hidup saja.

Pelaksanaan pembagian warisan dilakukan apabila semua unsur sudah terpenuhi. Mulai dari syarat, rukun, sebab dan mani' yang menjadi patokan dalam waris islam. Apabila unsur-unsur ini semua sudah terpenuhi, maka pembagian warisan sudah dapat dilaksanakan oleh sebuah keluarga. Karena itu, semua prosesi dalam kewarisan islam dilakukan sesuai dengan langkah-langkah yang telah di tetapkan. Untuk lebih jelasnya akan diuraikan sebagai berikut:

\section{a. Dasar hukum}

Secara umum, kewarisan islam merupakan dogma yang bersumber dari Alqur'an dan Sunnah Rasulullah Saw. Karena itu, dasar hukum pada semua prosesi pembagian warisan dapat difahami secara detail. Namunpun demikian, ada beberapa masalah waris islam yang diselesaikan secara ijtihad para ulama. Dalam Alqur'an, sejumlah kandungan ayat membicarakan secara global, namun 
mayoritas ayat-ayat terkait waris menguraikan tentang bagian-bagian setiap ahli waris secara detail ('Ajuz, 1986).

\section{b. Hak-hak yang berhubungan dengan harta peninggalan}

Istilah harta peninggalan merupakan hal dasar dalam pembagian warisan islam. Sebab harta warisan adalah bagian dari harta peninggalan. Sehingga tidak semua harta peninggalan menjadi harta warisan. Dengan istilah lain, harta warisan lebih khusus daripada harta peninggalan. Jadi, harta warisan merupakan sisa dari pengeluaran sejumlah hak-hak yang berkenaan dengan harta peninggalan. Di antara yang harus dikeluarkan dari harta peninggalan adalah biaya untuk pengurusan jenazah, membayar hutang-hutang dan menunaikan wasiat.(Qonun, 2010)

\section{c. Rukun kewarisan islam}

Pembagian warisan dalam islam dapat terjadi apabila rukunnya sudah terpenuhi. Seperti adanya pewaris, adanya ahli waris dan adanya harta warisan. Ketiga rukun ini merupakan pondasi utama dalam kewarisan islam. Sehingga, apabila salah satu rukun tidak terpenuhi, maka tidak disebut sebagai pembagian warisan. Pewaris adalah orang yang memberikan warisan atau dengan ungkapan lain bahwa pewaris adalah orang yang meninggalkan sesuatu kepada ahli waris, baik dalam bentuk hak ataupun harta warisan (Khalifah, 2005).

Kemudian, ahli waris dimaknai sebagi orang yang menerima harta dari si pewaris. Karena itu ahli waris dalam kewarisan islam mencakup semua garis kekerabatan pada umumnya. Mulai dari bagian suami atau istri, garis furu' (keturunan) yang meliputi anak dan cucu, garis ushul (asal) yang meliputi ayah, ibu, kakek dan nenek, garis hawasyi (kerabat samping) yang terdiri dari saudara, keponakan, paman dan sepupu (Khalifah, 2005).

Lebih lanjut, harta warisan merupakan istilah untuk sebutan bagi harta yang diterima oleh para ahli waris sepeninggal pewaris. Karena itu, harta yang akan dibagi oleh ahli waris adalah harta yang telah ditinggalkan oleh pewaris. Harta yang dijadikan sebagai warisan bersumber dari harta bawaan dan harta peninggalan si pewaris (Khalifah, 2005).

\section{d. Syarat kewarisan islam}

Syarat pembagian warisan merupakan turunan dari rukun pembagian warisan. Karena itu, yang menjadi syarat warisan adalah meninggalnya si pewaris, hidupnya ahli waris dan mengerti dengan metode pembagian warisan. Pembagian harta yang dilakukan sewaktu pewaris masih hidup tidak disebut sebagai warisan. Namun lebih tepatnya disebut sebagai hibah atau pemberian harta. Selain itu, ahli waris yang mendapatkan warisan hanya ahli waris yang masih hidup. Sedangkan ahli waris yang sudah meninggal dunia tidak mendapatkan warisan. Para ulama menjelaskan bahwa pengertian mati bagi pewaris dan hidup bagi ahli waris dapat dikategorikan sebagi haqiqi, hukmi dan taqdiri (Washil, 1995).

\section{e. Sebab kewarisan islam}

Istilah sebab dalam menerima warisan dalam ajaran islam merupakan faktor yang paling menentukan seseorang mendapatkan bagian atau tidak. Karena itu, sebab-sebab tersebut merupakan pintu masuk untuk menentukan apakah seseorang masuk kategori sebagai ahli waris atau tidak. Jadi, sebab-sebab 
seseorang mendapatkan warisan merupakan salah satu dari tiga sebab, yaitu sebab adanya hubungan pernikahan, sebab adanya hubungan nasab dan sebab karena memerdekakan hamba sahaya. Pada hubungan pernikahan dan hubungan nasab, ada take and gave, artinya apabila salah satu meninggal maka yang lain akan mendapatkan warisan. Dalam artian ketika istri meninggal dunia, maka suami mendapatkan warisan dan sebaliknya juga demikian. Ketika suami meninggal dunia, maka istri mendapatkan bagian. Pada hubungan nasab atau keturunan, ketika ayah meninggal dunia, maka anaknya akan mendapatkan warisan. Begitu juga sebaliknya ketika anak meninggal dunia, maka ayah mendapatkan warisan. Sementara itu, pada sebab karena memerdekakan hamba sahaya, maka yang mendapat warisan hanya orang yang memerdekakan saja (Washil, 1995).

\section{f. Mani' kewarisan islam}

Istilah mani' adalah hal-hal yang mempengaruhi seseorang terlarang untuk mendapatkan warisan. Faktor mani' menjadikan seorang ahli waris tidak berhak menjadi ahli waris lagi dan keberadaannya tidak dianggap ada. Selain itu, orang yang terhalang tersebut tidak dapat mempengaruhi bagian ahli waris yang lain. Adapun mani' dalam kewarisan islam adalah faktor pembunuhan, berbeda agama dan perbudakan (Shobuni, 2002).

Sejumlah dalil menjelaskan bahwa orang yang melakukan pembunuhan tidak mendapatkan warisan dari orang yang dibunuhnya tersebut. Lebih lanjut, di antara kaidah fiqh juga turut menjabarkan hal demikian. Yaitu kaidah yang menegaskan bahwa barang siapa yang menyegerakan sesuatu sebelum waktunya maka akan diganjar dengan mengharamkannya. Artinya bahwa pembunuh yang menghilangkan nyawa seorang pewaris membuat prosesi peralihan kepemilikan menjadi lebih cepat sebelum waktu yang seharusnya. Karena itu pembunuh diharamkan untuk mendapatkan dari apa yang seharusnya dia dapatkan (Shobuni, 2002).

\subsection{Nilai-nilai Maslahat Dalam Kewarisan Islam}

Maslahat atau kebaikan merupakan tujuan dari semua syariat dan ajaran islam. Karena itu pelaksanaan hukum sangat erat dengan kajian dampak yang akan ditimbulkan dari prakteknya. Sebab, nilai-nilai antara maslahat dan dampak mudhorat merupakan dua hal yang saling berhubungan. Mengantisipasi mudhorat lebih diutamakan dalam ajaran islam secara umum daripada meraih maslahat. Nilai-nilai maslahat boleh diamalkan apabila maslahat itu dapat diwujudkan, maslahat dapat berlaku untuk umum dan maslahat tidak bertentangan dengan nas yang sudah ada.

Sejumlah kaidah fiqh memiliki relevansi dalam kewarisan islam. Karena dalam kaidah tersebut mempunyai nilai-nilai maslahat yang dapat dirasakan dalam kewarisan islam. Selain itu kaidah tersebut juga dapat menjadi bagian dari landasan dalam penerapan kewarisan. Untuk lebih jelasnya akan diuraikan sebagai berikut:

\section{a. Kepastian}

$$
\text { اليقين لا يزول بالثك }
$$

Keyakinan tidak bisa hilang dengan sesuatu yang meragukan ('Azam, 2005). 
Jadi, sesuatu yang sudah tetap dan pasti tidak bisa dihilangkan dengan prediksi atau asumsi. Dalam konteks kewarisan islam bahwa orang yang merantau atau musafir ke tempat yang jauh dengan durasi waktu yang cukup lama, sehingga kondisinya tidak diketahui secara pasti. Hal yang demikian membuat sejumlah asumsi antara orang tersebut masih hidup atau sudah meninggal dunia. Maka dalam kewarisan islam, orang tersebut diyakini masih hidup selama tidak ada bukti yang menjelaskan bahwa orang tersebut sudah meninggal dunia.

Jadi, pada proses penentuan ahli waris pada kasus kematian, maka yang berhak untuk mendapatkan harta harus dipastikan bahwa ahli waris tersebut masih dalam keadaan masih hidup. Meskipun waktu hidupnya hanya berjarak hitungan durasi menit atau detik pada kasus munasakhat. Hal tersebut juga terjadi pada kasus janin yang masih berada di dalam kandungan. Janin dapat menjadi ahli waris apabila sudah diyakini dengan bukti bahwa janin tersebut berasal dari si pewaris.

\section{b. Konsekuensi}

$$
\text { من استعجل شيئا قبل أوانه عوقب بحرمانه }
$$

Barang siapa yang menyegerakan sesuatu sebelum waktunya maka dia akan disanksi dengan mengharamkannya ('Azam, 2005).

Dalam konsep kewarisan islam, orang yang membunuh pewaris, maka orang tersebut tidak akan mendapat harta warisan. Pada pembunuhan tersebut dianggap merupakan upaya untuk menyegerakan peralihan harta yang dimiliki oleh pewaris. Karena itu, pembunahan yang disengaja atau tidak disengaja menjadi penghalang untuk mendapatkan warisan. Sedangkan menurut imam syafi'l seluruh bentuk jenis pembunuhan termasuk qotlu al-haq (pembunuhan yang dibolehkan) juga merupakan penghalang mendapatkan warisan.

\section{c. Dinamis}

$$
\text { لايجوز لأحد أن يتصرف في ملك الغير بلا إذنه }
$$

Seseorang tidak boleh melakukan transaksi pada milik orang lain tanpa izin dari si pemilik ('Azam, 2005).

Makna kaidah ini adalah bahwasanya tidak diperbolehkan bagi seseorang untuk melakukan transaksi pada milik orang lain. Baik transaksi itu dalam bentuk perbuatan atau perkataan. Sehingga sebuah transaksi akad dianggap sah apabila yang melakukan transaksi tersebut adalah si pemilik atau orang lain yang berhak. Namun, pada proses kewarisan islam seseorang diperbolehkan untuk melakukan sebuah transaksi terhadap milik orang lain. Misalnya seseorang yang meninggal dunia tidak mempunyai ahli waris, lalu orang lain menginfakkan hartanya untuk hal-hal yang positif, maka perbuatan tersebut dianggap sah dan diperbolehkan. Karena tujuannya adalah untuk agama dan orang tersebut tidak mempunyai ahli waris. Dengan dilakukannya transaksi terkait harta si pewaris tersebut, maka hartanya dapat dimanfaatkan dan tidak menjadi sia-sia. Dalam ajaran islam dilarang melakukan perbuatan sia-sia dan tabdzir.

\subsection{Maqashid Syari'ah}

Maqashid dan syari'ah adalah dua kata yang berasal dari bahasa arab. Masing-masing mempunyai makna yang berbeda. Kata maqashid berasal dari kata قصد yang memiliki makna tujuan yang kuat atau maksud. Sedangkan kata 
syari'ah berasal dari kata شرع, yaitu jalan serta dimulainya suatu perbuatan. Sehingga gabungan kedua kata tersebut dapat dimaknai sebagai tujuan yang memiliki rahasia atas pelaksanaan hukum-hukum Allah Swt bagi umat islam(M. B. I. Habib, 1427). Karena itu, semua syariat Allah Swt mengandung maslahah bagi umat manusia secara umum (Khallaf, 2002).

Lebih lanjut, para ulama ushul fiqh menguraikan bahwa maqashid syari'ah mempunyai pengertian tertentu, yaitu sebuah tujuan yang diinginkan dari pelaksanaan syariat. Hal tersebut bertujuan untuk agar nilai-nilai dari tujuan syariat itu sendiri dapat dilaksanakan oleh umat manusia ('Asyur, 2011). Sebab, tujuan sesungguhnya dari syariat itu sendiri adalah untuk memberikan kemasalahatan bagi manusia. Jadi, maqashid syari'ah juga dimaknai sebagai asror asy-syari'ah, yaitu rahasia-rahasia serta hikmah dari pelaksanaan syariat (Khallaf, 2002).

Secara umum di antara tujuan dari pelaksanaan hukum syariat itu adalah untuk mewujudkan kemaslahatan bagi manusia dalam kehidupannya, baik di dunia maupun di akhirat. Proses tersebut dapat digapai dengan cara meraih sejumlah manfaat dan mengantisipasi hal-hal yang memberikan mudhorat kepada aspek agama, jiwa, akal, kehormatan dan keturanan serta akal. Pada akhirnya maslahat manusia yang akan dituju itu harus mempertimbangkan tiga unsur, yakni, kebutuhan dhoruriyah (pokok), kebutuhan hajiyah (sekunder) dan kebutuhan tahsiniyah (tersier atau mewah) (M. S. bin Ahmad, 1998).

Kebutuhan dhoruriyah dipahami sebagai hal pokok yang menyangkut kebutuhan dasar bagi manusia. Artinya jenis kebutuhan ini mau tidak mau harus ada, sebab apabila kebutuhan tersebut tidak terpenuhi, maka akan menimbulkan mudhorat dalam kehidupan seseorang. Karena jenis kebutuhan ini akan menyangkut secara langsung terkait dengan agama, jiwa, akal, kehormatan dan keturunan serta harta ('Azam, 2005).

Sementara itu kebutuhan hajiyah dimakanai sebagai kebutuhan jenis kelas kedua. Setelah kebutuhan dasar telah terpenuhi, maka manusia juga membutuhkan hal-hal yang membuat kehidupannya lebih mudah. Karena itu kebutuhan hajiyah bertujuan untuk memberikan maslahah dan menghindari kesulitan. Adapun kebutuhan tahsiniyah dimaknai sebagai kebutuhan untuk melengkapi dan menyempurnakan saja, sehingga apabila kebutuhan ini tidak terpenuhi, maka tidak akan mengganggu kehidupan manusia (Azhar, 2010).

\section{Kesimpulan}

Setelah diuraikan tentang nilai-nilai maslahat pada kewarisan islam, maka dapat disimpulkan bahwa kewarisan islam merupakan aturan yang sudah baku. Namun, sejumlah praktek kewarisan dapat berubah sesuai dengan konteks yang ada di lapangan. Banyak aspek maslahat yang sangat melekat dalam kajian kewarisan islam, sehingga membuat pintu ijtihad terbuka dalam bentuk lain untuk kemaslahatan ahli waris.

Kemudian, kewarisan islam menjamin hak seseorang sebagi ahli waris meskipun tidak diketahui keberadaannya secara pasti. Selain itu, hak kepemilikan seseorang diakui dan dijamin, sehingga peralihan harta miliknya setelah sepeninggalnya akan diteruskan kepada ahli warisnya. Kemudian, nilai-nilai maslahat juga terlihat dalam pengharaman warisan kepada orang yang membunuh si pewaris. Aturan ini akan menutup pintu niat seorang ahli waris untuk 
menghabisi jiwa seorang pewaris. Karena itu sejumlah praktek kewarisan islam berjalan dengan dinamis, agar dapat menjaga maslahat dhoruriyah, hajiyah dan tahsiniyah pada aspek agama, jiwa, keturunan, dan harta para pewaris.

\section{Daftar Pustaka}

'Ajuz, A. M. Al. (1986). Al Mirats Al 'Adil fi Al Islam baina Al Mawarits Al Qadimah wa Al Haditsah. Muassasah Al Ma'arif.

'Asyur, M. T. I. (2011). Maqashid Syari'ah Al-Islamiyah. Darul Kitab Al Masri.

'Azam, A. 'Aziz M. (2005). Al-Qowa'id Al-Fiqhiyah. Dar El Hadith.

Adnan, B. U. dan M. (2021). Application Of Islamic Inheritance Law Among Muslim Society. El-Arbah, 5(1), 19-32. https://doi.org/10.34005/elarbah.v5i1.1543

Ahmad, A. (2014). Reformulasi Konsep Maqashid Syari'ah Memahami Kembali Tujuan Syari'at Islam Dengan Pendekatan Psikologi. Hukum Islam, XIV(1), 45-63.

Ahmad, M. S. bin. (1998). Maqashid ASy-Syari'ah Al-Islamiyah wa 'Alaqotuha bi Al-Adillah Asy-Syar'iyyah. Daar Al Hijrah.

Al-'Ulwani, T. J. (2001). Qhodoya Islamiyah Mu'ashirah-Maqashid Syari'ah. Daar EL-Hadi.

Al-Badawi, Y. A. M. (1999). Maqashid Syariah Ibnu Taimiyah. Daar An-Nafais.

Amri, M. S., \& Tulab, T. (2018). Tauhid: Prinsip Keluarga Dalam Islam (Problem Keluarga Di Barat). In Ulul Albab: Jurnal Studi dan Penelitian Hukum Islam (Vol. 1, Issue 2). https://doi.org/10.30659/jua.v1i2.2444

Azhar, H. bin S. (2010). Maqashid Syari'ah 'Inda Imam Haramain. Maktabah Rusydi.

Basri, S. (2020). Hukum Waris Islam ( Fara' id ) dan Penerapannya dalam Masyarakat Islam. Jurnal Kepastian Hukum Dan Keadilan, 1(2), 37-46.

Franciska, S. A. A. dan W. (2021). Perlindungan Hukum Bagi Ahli Waris Terhadap Harta Warisan Yang Beralih Tanpa Persetujuan Seluruh Ahli Waris. Jurnal Kemahasiswaan Hukum Dan Kenotariatan, 1(1), 279-290.

Habib, M. B. I. (1427). Maqashid Syari'ah Ta'shilan wa Taf'ilan. Rabithoh Alam Islam.

Habib, M. S. (2017). Sistem Kewarisan Bilateral Ditinjau Dari Maqashid Al- Syari ' ah. De Jure: Jurnal Hukum Dan Syari'ah, 9(1), 30-42.

Indonesia, K. A. R. (2014). Al- Qur'ân al- Karîm dan Terjemahannya. Halim.

Jamal, R. (2010). Maqashid Al-Syariah dan Relevansinya Dalam Konteks Kekinian. Jurnal IImiah Al-Syir'ah, 8(1), 1-12.

Khalifah, M. T. A. A. 'Ala. (2005). Ahkam Al Mawarits Dirasah Tathbiqiyah. Dar Al Salam.

Khallaf, A. W. (2002). IImu Ushul Al Fiqh. Dar El Hadith.

Khodijah Ishak. (2014). Maqashid Syari'ah Dan Masalahah Dalam Ekonomi Dan Bisnis Syari'ah. Iqtisadhuna, 3(1), 659-672. 
Khotimah, K. (2014). Hukum dan Tujuannya Dalam Perspektif Hukum Islam. Mizani: Wacana Hukum, Ekonomi Dan Keagamaan, 1(2).

Lisma. (2019). Internalisasi Nilai Hukum Islam dalam Rancangan KUHP di Indonesia ( Studi terhadap Tindak pidana perzinahan dalam KUHP dan RKUHP ). EKSPOSE: Jurnal Penelitian Hukum Dan Pendidikan, 18(1), 721733.

Muhammad, H. H. (2013). Hukum Islam dan Maslahatnya di Indonesia. Al Syir'ah, 11(2).

Naskur. (2010). Memahami Harta Peninggalan Sebagai Warisan Dalam Perspektif Hukum Islam. Al Syir'ah, 8(1), 1-15.

Nasution, R. R. dan M. (2021). Sistem Waris Masyarakat Muslim Batak Angkola Dalam Tinjauan Alqur' an ( Studi Komparasi Surah An-Nisa Ayat 11, 12 dan 176 ). Asy-Syariah: Jurnal Hukum Islam, 7(2), 209-233. https://doi.org/10.36835/assyariah.v7i2.544

Qonun, L. Q. A. F. F. S. wal. (2010). Fiqh Al Mawarits. Universitas Al Azhar.

Ritonga, R. (2021a). Metode Hitungan Bagian Banci Dalam Waris Islam: Analisis Dan Praktik. Al-Hukama The Indonesian Journal of Islamic Family Law, 11(01), 76-104. https://doi.org/10.15642/alhukama.2021.11.01.76-104

Ritonga, R. (2021b). The First Class Of Women Heir Member In The Observation Of Surah An-Nisa Ayat 11, 12 , DAN 176. Al- ' A Dalah: Jurnal Syariah Dan Hukum Islam, 6(1), 1-17. https://doi.org/10.31538/adlh.v6i1.1362

Sa'adah, S. L. (2015). Maqashid Al-Syari'ah Dalam Hukum Kewarisan Islam. AlAhwal, 7(1), 125-146.

Shidiq, G. (2009). Teori Maqashid Al -Syari'ah Dalam Hukum Islam. SULTAN AGUNG, XLIV(118), 117-130. https://doi.org/10.1001/archneur.58.4.677

Shobuni, S. M. A. (2002). Al Mawarits fi Asy-Syari'ah Al- Islamiyah fi Dhoui Al Kitab wa As Sunnah. Daar Ash Shobuni.

Suratmaputra, A. M. (2017). Kemaslahatan Sebagai Tujuan Pensyari'atan Hukum Islam : Misyakat, 02(02), 1-20.

Washil, N. F. M. (1995). Fiqhu Al Mawarits wa Al Wasiyah. Dar Al Salam. 